\title{
KACHLE S PĚTI KRUHOVÝMI PROHLUBNĚMI Z AREÁLU MĚSTA LITOVLE
}

\section{LUKÁŠ HLUBEK}

\begin{abstract}
Abstrakt: Předložený článek se zabývá kachli s pěti kruhovými prohlubněmi na čelních vyhřivacích stěnách z areálu města Litovle. Tyto kamnářské výrobky byly ziskány v prủběhu posledních dvou desetiletí při záchranných archeologických výzkumech v historickém jádru města i mimo něj. Kachle s pětici prohlubní lze klást do druhé poloviny 16. až prvni poloviny 17. století. Obvykle bývaji považovány za typický výrobek novokřtěnských hrnčirư, ale je velmi pravděpodobné, že v prípadě litovelských nálezů jde o produkty lokálni inspirované novokrtěnskou hrnčiřskou tvorbou.
\end{abstract}

Klíčová slova: Litovel - kachle - raný novověk - novokřtěnské výrobky - napodobenina.

\section{Tiles with Five Circular Dimples from the Town of Litovel}

Abstract: This article discusses tiles with five circular dimples on the front (heated) walls from the town of Litovel. These stove products were unearthed in the course of rescue archaeological research in the historical centre of the town and outside it in the last two decades. The tiles with five circular dimples can be placed in the second half of the 16th century or the first half of the 17th century. These tiles are usually considered typical products of Anabaptist potters; however, the Litovel finds are probably local products inspired by Anabaptist pottery.

Key words: Litovel - tiles - early modern age - Anabaptist products - imitation.

\section{Úvod}

V současné době probíhá postupné zpracování souborů kamnářské keramiky z areálu města Litovle. Dnes už disponujeme vyhodnocením drtivé většiny kachlů ze sbírky bývalého Okresního vlastivědného muzea v Litovli (např. Hlubek 2012; 2013; 2013a; 2013b) a od loňského roku jsou postupně zveřejňovány vybrané exempláře i celé kolekce z výzkumů vedených pracovníky Národního památkového ústavu, územního odborného pracoviště v Olomouci (např. Hlubek-Faltýnek 2016; Hlubek-Faltýnek-Šlézar 2016; Hlubek-Šlézar 2016; Hlubek 2017). Zejména v souborech kamnářské keramiky kladených do raného novověku byly nacházeny exempláře s pěti kruhovými prohlubněmi na čelních vyhřívacích stěnách (dále ČVS) ${ }^{1}$ které téměř jako jediné evidujeme $\mathrm{z}$ několika různých archeologických výzkumů. Jednotlivé nálezy zaznamenáváme v historickém centru města a v areálu Starého města u Litovle, odkud evidujeme dosud nejrozsáhlejší konvolut kachlů.

\section{Nálezové okolnosti kachlů s motivem pěti miskovitých prohlubní v Litovli}

V posledních dvou desetiletích proběhlo v Litovli značné množství archeologických výzkumů, jejichž výsledky nebývalou měrou přispěly k poznání dějin města Litovle (souborně Šlézar 2016, 27-155). Je však nutné poznamenat, že většina terénních zásahů byla prováděna $\mathrm{v}$ rámci různých liniových výkopů a jen $\mathrm{v}$ omezeném rozsahu docházelo $\mathrm{k}$ výzkumům souvislejších ploch, jako například během rekonstrukce Náměstí Přemysla Otakara v roce 2014 nebo na Zahradní ulici (Šlézar 2006, 255; Faltýnek-Šlézar-Zlámal 2015, 4-14).

Dnes registrujeme kamnářské výrobky s pěti kruhovými prohlubněmi na ČVS celkem ze šesti archeologických výzkumů na současném katastru města Litovle. Kachle pocházejí z historického jádra města, a to z interiéru kostela sv. Marka, z ulic Komenského, Revoluční, Masarykovy a Husovy. ${ }^{2}$ Poslední lokalitu nalezneme v prostoru tzv. Starého města u Litovle na dnešní Zahradní ulici.

1 Pro kachle s tímto „motivem“ lze v literatuře dohledat i jiné názvy, např́klad šálkovité, s mísečkovitými či miskovitými prohlubněmi (např̀. Lansfeld 1950, 92; Bielich 2012, 203; Tymonová 2015, 949).

2 Nově se podařilo identifikovat další zeleně glazovaný zlomek kachle s částečně dochovanou jednou prohlubní mezi materiálem $\mathrm{z}$ výzkumu na náměstí Svobody v Litovli. Děkuji touto cestou K. Faltýnkovi za upozornění. 
Kostel sv. Marka (obr. 1:1)

Během povodní v roce 1997 došlo k narušení statiky kostela sv. Marka v Litovli. V roce 1999 byl v interiéru kostela proveden záchranný archeologický výzkum vedený K. Faltýnkem. Z výzkumu pochází značně rozsáhlý konvolut nálezů (např. fragmenty keramiky, části renesančních náhrobků, antropologický materiál, kusy omítky, střešní krytina, rozličné drobné kovové nálezy, psací pomůcky atd.). V místech pod severní kruchtou a v prostoru presbytáře se podařilo vyzvednout také jedenáct fragmentů raně novověkých kachlů (Faltýnek 2000, 76-82; FaltýnekŠlézar 2006, 309-315; Šlézar 2008, 36-44). V získané kolekci je nejlépe rozpoznatelný právě zlomek s částečně dochovanou kruhovou prohlubní a stylizovaným liliovým kvítkem. Ten se podařilo identifikovat na okrajovém zlomku kachle s širší hranolovou lištou a částí ČVS, která je pokryta světle zelenou glazurou na bílé hlince (obr. 2:4).

\section{Ulice Komenského (obr. 1:2)}

V rámci plánované novostavby rodinného domu s provozovnou čp. 687 byl realizován záchranný archeologický výzkum. Ve dvou sondách byly v hloubce $0,8 \mathrm{~m}$ zachyceny středověké vrstvy ze 14. až 15. století (Faltýnek-Šlézar 2005, 290-291). V materiálu se vyskytuje také sedm fragmentů režných i zeleně glazovaných komorových kachlů, které lze klást do raného novověku. Mezi nimi se nachází jeden zlomek se sledovaným „motivem“ na ČVS. Jeho okraj tvoří hranolová lišta se zaoblením a povrch pokrývá světle zelená glazura (obr. 2:2).

\section{Ulice Revoluční (obr. 1:3)}

V roce 2000 proběhl záchranný archeologický výzkum ve dvoře domu čp. 728. V základové rýze se podařilo zachytit kulturní souvrství z 15. až 18. století (Faltýnek 2001, 216). Mezi nálezy byly identifikovány čtyři zlomky komorových kachlů z druhé poloviny 15 . až počátku 17. století. Jednoznačně určitelné je pouze torzo většího fragmentu ČVS s částí jedné kruhové prohlubně. ČVS je opatřena světle zelenou glazurou na bílé podkladové hlince (obr. 2:3).

\section{Ulice Masarykova (obr. 1:4)}

V roce 2008 byly ve dvoře domu čp. 764 vyhloubeny celkem tři kanalizační šachty. V jedné z nich byla odkryta kulturní vrstva z 16. století, která mimo jiné obsahovala šest kusů kamnářské keramiky (Faltýnek-Šlézar 2009, 400). Nejlépe se dochovaly tři čtvrtiny režného komorového kachle, na jehož ČVS nacházíme čtyři z pěti prohlubní. Centrální prohlubeň je rámována tenkou plastickou lištou, jejíž vrcholy zdobí stylizované liliové kvítky (obr. 4).

\section{Ulice Husova (obr. 1:5)}

V roce 2001 realizovali pracovníci památkového ústavu archeologický výzkum v souvislosti s budováním veřejného WC za domem čp. 754 na Husově ulici. Zjištěné kulturní vrstvy obsahovaly především raně novověký materiál a několik málo zlomků stolní a kuchyňské keramiky ze 14. nebo 15. století. Mezi nálezy se vyskytuje také deset fragmentů kachlů $\mathrm{z}$ druhé poloviny 16. až počátku 17. století (Faltýnek 2012, 41, obr. 5:6, 15). Pro nás je podstatný pouze zeleně glazovaný fragment ČVS kachle s částečně dochovanou tenkou lištou ukončenou stylizovaným liliovým kvítkem a jednou neúplnou kruhovou prohlubní (obr. 2:1).

\section{Ulice Zahradní (obr. 1:6)}

Záchranný archeologický výzkum zde proběhl v souvislosti s výstavbou rodinného domu, navazujícího na stávající řadovou zástavbu. Na ploše $107 \mathrm{~m} 2$ byla zachycena část sídliště lužické kultury a také objekty i kulturní vrstva z pozdní doby hradištní. Oba tyto horizonty následně narušil rozsáhlý raně novověký zahloubený objekt. Patrně se jednalo o stavbu hospodářského charakteru o šířce $6,3 \mathrm{~m}$, byla zkoumána $\mathrm{v}$ délce $6 \mathrm{~m}$. Nálezová situace působí dojmem, že zde došlo k jednorázovému vysypání většího množství raně novověké keramiky do objektu. Z jeho výplně se podařilo vyzvednout značné množství standardní raně novověké hrnčiny a komorových kachlů (Šlézar 2006, 255; Hlubek-Šlézar 2016, 51-58). V kolekci kamnářské keramiky se vyskytují 


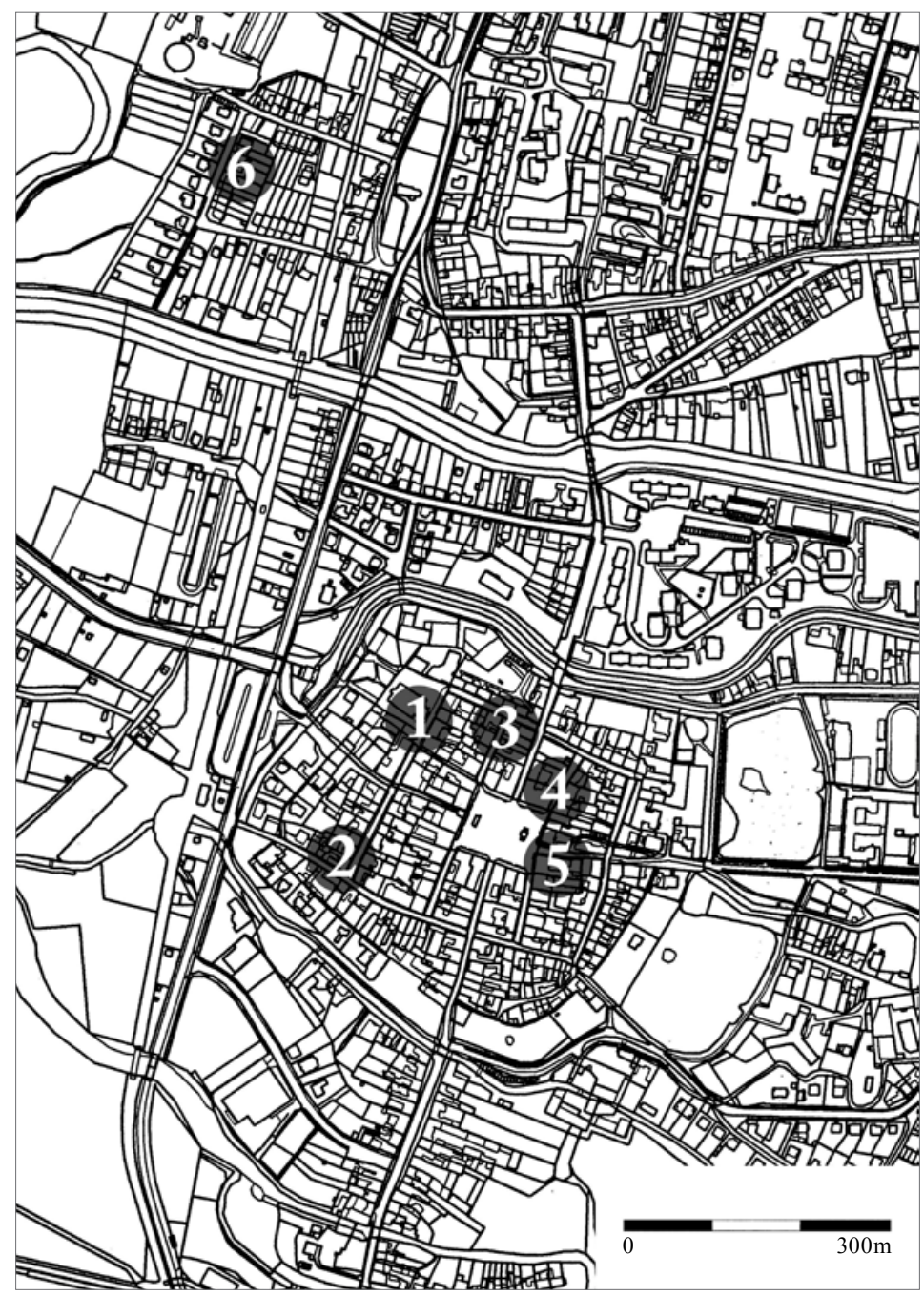

Obr. 1. Litovel. Poloha míst s nálezy kachlů s pěti kruhovými prohlubněmi. 1 - Kostel sv. Marka, 2 - Komenského ulice, 3 - Revoluění ulice, 4 - Masarykova ulice, 5 - Husova ulice, 6 - Zahradní ulice. Digitalizace J. Grégr, upravil P. Rozsíval.

Abb. 1. Litovel. Lage der Fundstellen von Kacheln mit fünf kreisförmigen Vertiefungen. 1 - St. Markuskirche, 2 - Straße Komenského, 3 - Straße Revoluční, 4 - Straße Masarykova, 5 - Straße Husova, 6 - Straße Zahradní. Digitalisierung J. Grégr, bearbeitet von P. Rozsíval.

také zeleně glazované zlomky komorových kachlů opatřených pěti kruhovými prohlubněmi. Podařilo se slepit dva větší kusy, na nichž je centrální prohlubeň rámována tenkou kruhovou lištou se stylizovanými liliovými kvítky (obr. 3:1, 2). Je vysoce pravděpodobné, že k této skupině lze přiřadit i rohové varianty kachlů se šikmo seříznutou komorou a dvěma prohlubněmi s liliovým dvojkvítkem uprostřed na ČVS (obr. 5). Je také možné, že oba typy kachlů pocházejí z jednoho kamnového tělesa (Hlubek-Šlézar 2016, 56). 


\section{Popis a analýza kamnářské keramiky}

Celkově máme k dispozici jeden tříčtvrteční exemplář s částečně dochovanou komorou, tři větší slepená torza a 23 menších fragmentů základních i rohových kachlů (obr. 2-5). Základní variantě náleží celkem 18 kusů, na jejichž ČVS předpokládáme celkem pět kruhových prohlubní. Jak naznačují analogické nálezy, čtyři prohlubně jsou umístěny v jednotlivých rozích a pátá uprostřed ČVS. Jejich průměr se pohybuje okolo $55 \mathrm{~mm}$ a od zbytku ČVS nejsou nijak zvlášt' odděleny. Rohové výrobky se dvěma kruhovými prohlubněmi na ČVS byly identifikovány celkem na devíti zlomcích (obr. 4). Také v tomto prrípadě nejsou kruhové prohlubně nijak výrazně odděleny od zbytku ČVS a mají v podstatě totožný průměr.

Jen ve dvou př́ípadech víme jistě, že ČVS má obdélný tvar. U základního kachle z Masarykovy ulice známe i přesné rozměry, které činí $245 \times 233 \mathrm{~mm}$ (obr. 4), a jsme schopni aspoň přibližně odvodit rozměry u rohové varianty $-240 \times 107-110 \mathrm{~mm}$ (obr. 5). U ostatních kusů nelze jednoznačně rozhodnout, zda měly čtvercový, či obdélný formát. Na zpracovávaném materiálu se podařilo identifikovat celkem čtyři druhy okrajových lišt. Méně se vyskytuje širší hranolová lišta (obr. 2:4) nebo trojnásobná hranolová (obr. 2:3); vyšší zastoupení má lišta v podobě šikmo seříznutého hranolu (obr. 3:2). ${ }^{3}$ Nejčastěji zaznamenáváme okrajové lišty hranolové se zaoblením (obr. $2: 2 ; 4 ; 5)$.

Výzdobné prvky na ČVS představují tenké plastické lišty, rámující centrální prohlubeň, ukončené stylizovanými liliovými kvítky. Tato lišta může mít tvar bud' kruhový se čtyřmi půlkruhovými výstupky (obr. 3:1,2), nebo v podstatě kosodélníkový s trojnásobně prohnutými rameny (obr. $2: 1$; 4). Kachle se dvěma prohlubněmi jsou zdobeny pouze liliovým dvojkvítkem uprostřed ČVS (obr. 5). ${ }^{4}$ Odlišné provedení mají také stylizované liliové kvítky. U nálezů ze Zahradní ulice mají téměř kotvovitý tvar (obr. 3:1, 2; 5), kdežto u kachlů z historického jádra mají zřetelné kontury tří lístků (obr. 2:1, 4; 4). Je zřejmé, že výše uvedené kamnářské výrobky pocházejí minimálně ze tř́ různých forem, které se od sebe v drobných detailech odlišovaly.

Zaměříme-li se na technologickou stránku výše popsaného kamnářského materiálu, je možné uvést následující poznatky. Pouze největší fragment má režný povrch, všechny ostatní kusy mají bud' světle, či sytě zelenou glazuru, která zpravidla spočívá na bílé podkladové hlince. Kachle z Revoluční a Zahradní ulice pokrývá na hranách ještě hnědá glazura. Keramická hmota byla hrnčířem důsledně připravena, nebot' obsahuje pouze jemnozrnné ostřivo, které jen ojediněle prostupuje na povrch. V̌̌echny exempláře mají kvalitní homogenní výpal. Barva střepu osciluje od téměř oranžových odstínů až po sytější cihlovou. Na 25 kusech evidujeme na zadní straně vrstvu sazí dokládající jejich užití v kamnovém tělese. Na zadní straně jednoho většího torza (obr. 3:2) zaznamenáváme otisk hrubé textilie, která sloužila k lepšímu zatlačení keramické hmoty do matrice při výrobě.

Celou komoru litovelských kamnářských výrobků evidujeme pouze u jednoho základního a jednoho rohového kachle (obr. 4, 5). Komory jsou rámové, s celkovou hloubkou $55 \mathrm{~mm} u$ základního kusu a $39 \mathrm{~mm}$ u rohového. Je možné předpokládat, že i v dalších případech mohly být popisované výrobky opatřeny rámovou komorou. U rohových exemplářů zaznamenáváme šikmé seříznutí komory tak, aby mohlo dojít k sesazení dvou kusů a vytvoření nároží kamen (obr. 5).

\section{Datování}

$\mathrm{V}$ obecné rovině můžeme kamnářskou keramiku s dvěma či pěti kruhovými prohlubněmi klást do raného novověku, což naznačuje výrazné zmenšení hloubky komory kachle, výskyt otisku hrubší textilie na rubových stranách výrobků, zelená glazura na ČVS nebo také složitější

\footnotetext{
3 Nelze vyloučit, že tento typ okrajové lišty vznikl díky dlouhodobému uživaní formy k výrobě kachlů, kdy původní hranolová lišta měla být opatřena zaoblením, jako u rohové varianty kachle (srov. obr. 4). Doplňme ještě, že liliové dvojkvítky na ČVS mají kvalitnější provedení a ostřejší reliéf než základní výrobky (srov. obr. 3:1, 2; obr. 5).

4 Zdobenou ČVS evidujeme ještě na fragmentu kachle z brněnského minoritského kláštera, kterou ještě zkrášluje vegetabilní motiv (srov. Jordánková-Loskotová 2005, 452, obr. 18), a na jednom rekonstruovaném exempláři z Podivína (Pajer 1997, 192, obr. 6). U ostatních nálezů žádnou další výzdobu neznamenáváme.
} 

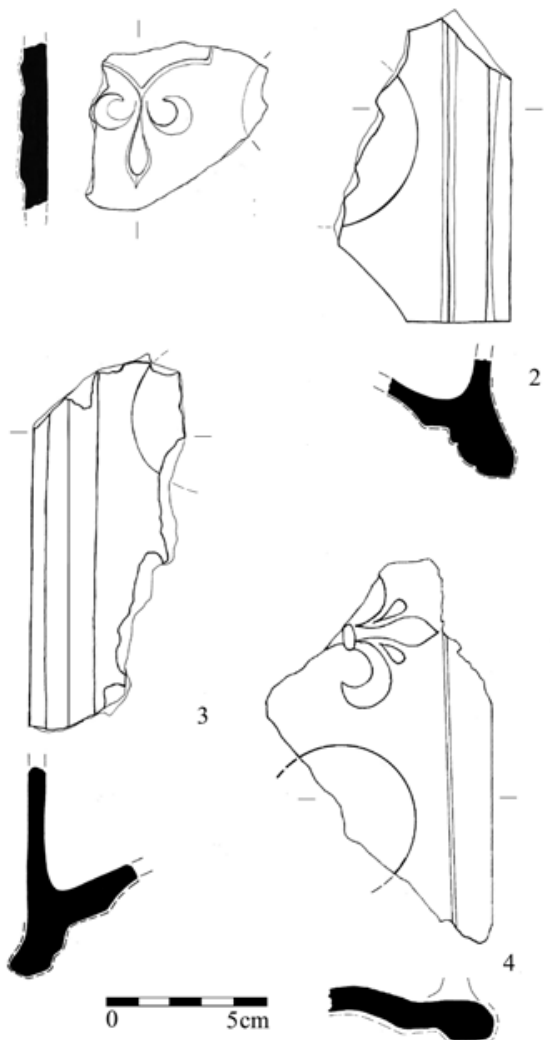

Obr. 2. Litovel. Základní kachle s pěti kruhovými prohlubněmi. 1 - Husova ulice, 2 - Komenského ulice, 3 - Revoluční ulice, 4 - Kostel sv. Marka. Kresba L. Hlubek, M. Sklenovská.

Abb. 2. Litovel. Grundkacheln mit fünf kreisförmigen Vertiefungen. 1 - Straße Husova, 2 - Straße Komenského, 3 - Straße Revoluční, 4 - St. Markuskirche. Zeichnung L. Hlubek, M. Sklenovská.
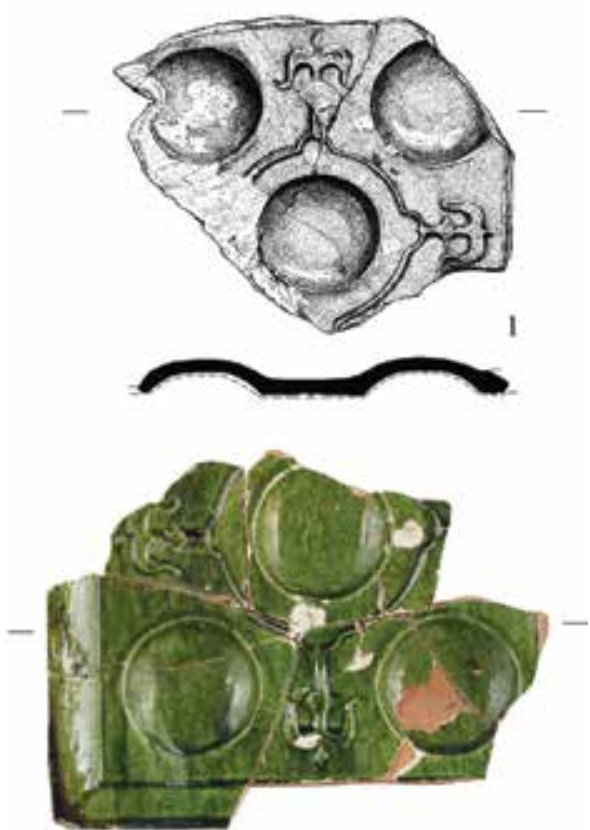

2

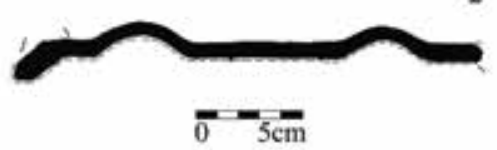

Obr. 3. Litovel. Základní kachle s pěti kruhových prohlubní. 1, 2 - Zahradní ulice. Kresba I. Hradilová, fotografie P. Rozsíval.

Abb. 3. Litovel. Grundkachel mit fünf kreisförmigen Vertiefungen. 1, 2 - Straße Zahradní. Zeichnung I. Hradilová, Foto P. Rozsíval.

profilace okrajových lišt (např. Hazlbauer-Špaček 1986, 157-163; Krasnokutská 2005, 58-61). Z již publikovaných souborů obsahujících kachle s pěti kruhovými prohlubněmi můžeme zmínit rozsáhlou kolekci kuchyňské a stolní keramiky nalezenou spolu s kachli z areálu Starého města, která byla zařazena do druhé poloviny 16. až první poloviny 17. století (Hlubek-Šlézar 2016, 51-58). V podstatě do stejného časového intervalu je kladen zlomek kachle s liliovým kvítkem (obr. 2:1) i standardní hrnčina vyzvednutá při výzkumu na Husově ulici (Faltýnek 2012, 41).

$\mathrm{Z}$ výše uvedené datace poněkud vybočuje fragment kachle získaný v interiéru kostela sv. Marka v Litovli. Ten pochází z vrstvy, která je ztotožňována s barokní přestavbou kostela v letech 1675-1677 (Faltýnek-Šlézar 2006, 309; Šlézar 2008, 28, 39). Vrstva kromě kamnářské keramiky obsahovala běžnou stolní keramiku, stavební články, zlomky renesančních náhrobků, antropologický materiál, fragmenty malovaných omítek atd. Je však možné připustit, že se v této vrstvě vyskytuje i tzv. terciární odpad (k tomu Čapek 2010, 26-27), takže i tento exemplář může reálně korespondovat s výše uvedeným datováním. 


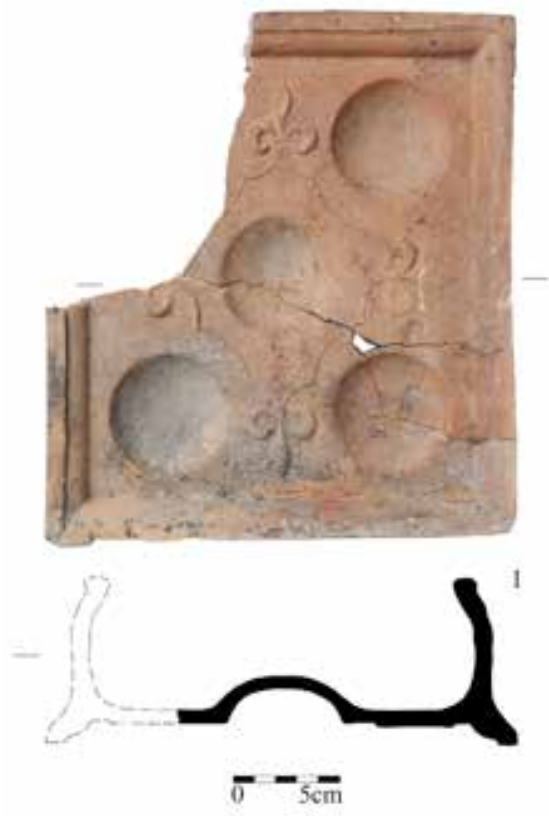

Obr. 4. Litovel. Základní kachel s pěti kruhovými prohlubněmi. 1 - Masarykova ulice. Kresba I. Hradilová, fotografie P. Rozsíval.

Abb. 4. Litovel. Grundkachel mit fünf kreisförmigen Vertiefungen. 1 - Straße Masarykova. Zeichnung I. Hradilová, Foto P. Rozsíval.

obr. 13:3-5; Loskotová 2008, 143, kat. č. 515; Holub-Jordánková-Loskotová 2009, 282, fig. 24 Pavlík 2011, 564, 570, obr. 7:3; Goš-Karel 2011, 78, tab. 9:1; Ruttkay 2008, 129, B102, B104; Bielich 2012, 203-204, obr. 4:8; Loskotová-Dragoun-Kocman 2013, 196, obr. 92; Pajer 2015, 53; Wintrová 2016, 24, obr. 16, kat. č. 18).

\section{Provenience}

Kamnářské výrobky s pěti kruhovými prohlubněmi na ČVS vykazují značnou př́ibuznost se skupinou kachlů s centrálním medailonovým zahloubením (např. Pajer 1983, 109-110; Loskotová 2009, 24-25). Oba tyto typy výrobků považujeme za charakteristický produkt novokřtěnských hrnčířù. Setkáváme se s nimi především v prostředí jejich dílen v prostoru jižní Moravy, kde se usídlily první skupiny novokřtěnců roku 1526. Na Moravě se novokřtěnci zdržovali až do roku 1622, kdy byli definitivně vypovězeni a odešli do Uher (k tomu Pajer 2006, 5). Pro nás je podstatné, že dokázali vyrábět vysoce kvalitní hrnčířské i kamnářské výrobky, které si získaly značnou oblibu na trhu. $\mathrm{V}$ případě produkce kachlů došlo $\mathrm{k}$ okopírování původních předloh a následně k jejich napodobování i v odlehlejších částech Moravy a Slezska (např. Pajer 1983, 100-103; Loskotová 2009, 18-19; Tymonová 2015, 948).

Dosud známé nalezené kachle s pěti kruhovými prohlubněmi z prostředí novokřtěneckých dílen ale nemají středovou prohlubeň nijak orámovanou plastickou lištou, jako je tomu u kachlů nalezených v Litovli. Pro úplnost dodejme, že z novokřtěnských lokalit známe také kachle čtvercového formátu s centrálním terčíkem a tenkou lištou tvořící kosočtverec s prohnutými rameny, v jehož vrcholech nacházíme liliové kvítky (srov. Pajer 1983, obr. 57:4; 1998, 171-173, obr. 13; 2006, 114, obr. 10). Pro ně shledáváme volnou paralelu v kamnářském materiálu z Mnišské ulice v Opavě (Krasnokutská 2005, 41, tab. 37:3, 4). Je možné připustit, že právě v těchto dvou 

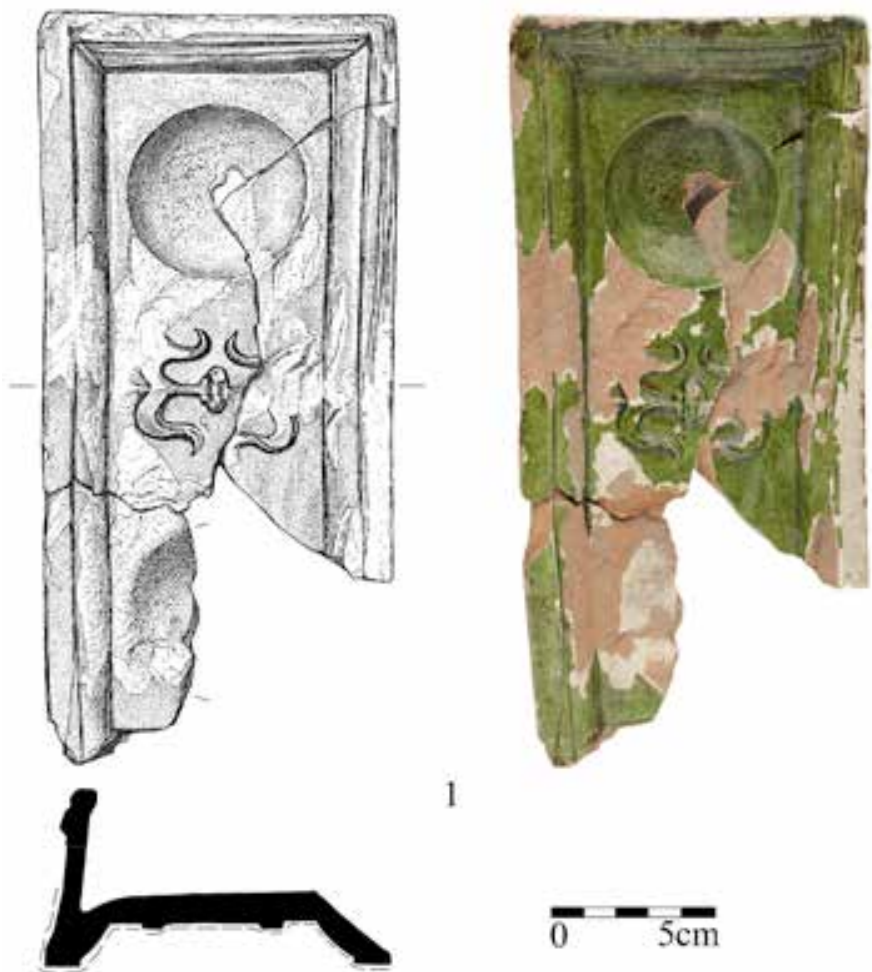

Obr. 5. Litovel. Rohové kachle s motivem dvou kruhových prohlubní. 1 - Zahradní ulice. Kresba I. Hradilová, fotografie P. Rozsíval.

Abb. 5. Litovel. Eckkachel mit Motiv zweier kreisförmiger Vertiefungen. 1 - Straße Zahradní. Zeichnung I. Hradilová, Foto P. Rozsíval.

„motivech“ na ČVS kachlů můžeme hledat inspirační zdroj pro výše prezentované litovelské exempláře.

Odlišný je také způsob výroby rohových kachlů. V př́ípadě nálezů z města Litovle vytvářely dvojice kachlů nároží se šikmo seříznutou komorou (obr. 5) tak, aby je bylo možné sesadit k sobě. ${ }^{5}$ U novokřtěnských výrobků evidujeme výrobně náročnější variantu rohového kachle se zkoseným nárožím, přičemž tato stěna může být rovná či ukončená trojúhelníkovitou patkou. Jedna ČVS je hladká a na druhé jsou dvě kruhové prohlubně (např. Pajer a kol. 2002, 182, obr. 102:8; Pajer 2006, 220, 13:7). ${ }^{6}$

Prezentované nálezy z Litovle je možné označit za napodobeniny vycházející z novokřtěnských předloh. V písemných pramenech zaznamenáváme v Litovli mezi lety 1493-1497 hrnčíře Pavla v Králově uličce na Starém městě. Znovu se $\mathrm{s}$ hrnčíři setkáváme až v druhé polovině 16. století v rychtářské knize. Samotný hrnčířský cech byl ve městě založen v úterý na den sv. Markéty (13. července) roku 1593. Z dosud provedených archeologických výzkumů neznáme přesné místo, kde se nacházely jejich dílny. Zatím je možné vycházet pouze z nepřímých písemných zpráv a toponyma Hrnčířská ulice, které naznačují umístění dílen do prostoru Starého města, což také podporují objevené defektní výrobky „litovelské lidové hrnčiny“ v těchto místech. Zda litovelští řemeslníci zhotovovali kachle se sledovaným motivem, zatím není možné

5 Podobně seříznuté komory kachlů známe i z kolekce kamnářské keramiky z Chořelic (Hlubek-Faltýnek 2016, 117) a na dalším rohovém kachli ze Zahradní ulice (Hlubek-Šlézar 2016, 56, obr. 8:2).

6 Jinou variantu rohového medailonového kachle známe např́iklad z předměstí Uničova (Faltýnek 2013, 16, obr. 2:1). 
jednoznačně rozhodnout (např. Pinkava 1903, 127; Hrbková 1970, 5-7; Bezdečka 1993, 135; Faltýnek-Šlézar 2015, 274-276).

Nicméně v této souvislosti lze jako jedno z možných míst výroby uvést blízké hrnčířské centrum v Lošticích, kde byly vedle stolní a kuchyňské keramiky zhotovovány také kachle. Výrobu kamnářského zboží nám naznačují jak dvě formy (Hlubek 2015), tak zmínky v literatuře o nálezech nepoužívaných kachlů na střepištích (např. Lang 1957, 29-30). Z nově získaných nálezů z Loštic můžeme připomenout kolekci keramiky z jámy č. 17 na Hradské ulici. Podle V. Goše zásyp tohoto objektu tvořil původní výmět z pece. $Z$ objektu bylo vyzvednuto celkem 700 kusů keramiky, přičemž na úrovni začištěné plochy se podařilo nalézt zlomky medailonových kachlů označovaných jako typické výrobky novokřtěnců (Goš 2007, 24, 29, 73). Na tomto místě můžeme uvést také poznámku V. Houdka, že z Loštic pocházejí kachle s „polovypnulinkami“ (Houdek 1891, 61). Z této zmínky V. Goš vyvozoval, že jde o kachle s centrálním medailonem, jaké nalezl v jámě č. 17 (2007, 73). Nelze však jednoznačně vyloučit možnost, že šlo právě o kamnářské výrobky s pěti kruhovými prohlubněmi na ČVS.

Na základě výše uvedených skutečností předpokládáme, že ke zhotovování kachlů s pěti kruhovými prohlubněmi docházelo také někde v prostoru střední Moravy. Za současného stavu nelze vyloučit, že je produkovalo více dílen současně. ${ }^{7}$ Napomoci by mohly petrografické analýzy vybraných exemplářủ s totožnými motivy. Na základě výsledků je možné spojit jednotlivé nálezy s původními hrnčířskými dílnami (např. Hložek-Loskotová 2015, 458-459).

Dodejme ještě, že ve druhé polovině 16. a v průběhu 17. století vlastnili město Litovel dva rody - Boskovicové a Lichtenštejnové. Páni z Boskovic vymřeli po meči roku 1597 a následně město přešlo na Lichtenštejny. Oba tyto rody měly své statky také v prostoru jižní Moravy, kde se usadily skupiny novokřrtěnců. Je nutné připomenout, že zvláště páni z Boskovic byly známí svou náboženskou tolerancí. Ostatně jedné skupině novokřtěnců vedené Oldřichem Stadlerem umožnil usadit se v Bučovicích Václav Bučovický, otec posledního mužského potomka Jana Šembery z Boskovic, který měl v druhé polovině 16. století v držení město Litovel (např. Dufková 2014, 119-120, 125). Za této situace si lze představit, že věhlas či obliba novokřtěnských výrobků mohla proniknout do Litovle prostřednictvím majitele města či osob vyskytujících se v jeho blízkosti. ${ }^{8}$ Poznamenejme ještě, že olomoucký biskup si na konci 16. století pro svou rezidenci na olomouckém Předhradí objednal u novokřtěnců kamna pro svůj pokoj ,z pěkných modrých neb nebeské barvy kachlikưv a do jiných zelené barvy“ (Jakubec 2003, 260).

\section{Závěr}

Z areálu města Litovle evidujeme $\mathrm{z}$ šesti míst kachle s pěti kruhovými prohlubněmi a také jejich rohové varianty s dvěma kruhovými prohlubněmi. Na základě rozdílů v provedení okrajových lišt a plastické výzdoby na ČVS usuzujeme, že prezentované výrobky pocházejí minimálně ze tří různých kadlubů. Podle charakteristických technicko-technologických poznatků i analogických nálezů z území Moravy a Slovenska je můžeme klást do raného novověku, přesněji do časového intervalu od druhé poloviny 16. století až do první poloviny následného věku. Kachle s pěticí kruhových prohlubní bývají obvykle považovány za charakteristický výrobek novokřtěnských hrnčířu $\mathrm{v}$ uvedeném období. Na základě rozboru materiálu se domníváme, že $\mathrm{v}$ prŕípadě litovelských nálezů jde spíše o lokální produkty jedné nebo více středomoravských kamnářských dílen, jejichž hrnčíři se inspirovali novokřtěneckou kamnářskou tvorbou. ${ }^{9}$

\footnotetext{
7 Na střední Moravě zatím nedošlo k publikaci dvou objevených kamnářských dílen, a to z Olomouce Hrnčířské ulice a z Přerova v poloze Na Marku (např. Tymonová 2014, 158, i s další literaturou), které by mohly výrazně zvýšit naše povědomí o kamnářském zboží z těchto výrobních center a také o následné distribuci jejich produktů v prostoru střední Moravy.

8 Podnětnou práci publikovala V. Říhová, která se zabývala kachli se znakem olomouckého biskupa Karla z Liechtensteinu-Castelcorna z průběhu druhé poloviny 17. století. Z jejího textu vyplývá, že původně polychromně glazované kachle s biskupským znakem vyráběl vyškovský hrnčír Jan Čech a následně se jeho výrobky napodobili hrnčíri z Kroměříže (Ř́íhová 2010, 212-213).

9 Děkuji touto cestou za př́nosné rady PhDr. J. Pajerovi, CSc.
} 


\section{Literatura}

BEZDĚČKA, J., 1993: Dějiny města Litovle od počátku do února 1948, 1. díl. Rkp. ulož. ve Vědecké knihovně v Olomouci.

BIELICH, M., 2012: Nálezy neskororenesančných kachlíc z Oponického hradu (16.-17. storočí), Acta historica Neosiliensia 15, 200-209.

ČAPEK, L., 2010: Depoziční a postdepoziční procesy středověké na parcelách Českých Budějovic - The formational and postdepozitional study of pottery on high middle ages house plots in České Budějovice. Plzeň.

DUFKOVÁ, K., 2014: Jan Šembera z Boskovic. Moravský Petr Vok. Praha.

FALTÝNEK, K., 2000: Záchranný archeologický výzkum v kapli sv. Jiří a kostele sv. Marka v Litovli. Památkový ústav v Olomouci - Archäologische Rettungsuntersuchung in der Kapelle H1. Georg und in der Pfarrkirche Hl. Markus in (Litovel) Littau. Památkový ústav v Olomouci. Výroční zpráva 1999, 76-82.

- 2001: Litovel (okr. Olomouc), PV 42, 216.

- 2012: Litovelské masné krámy ve světle historických pramenů a archeologických výzkumů - Die Fleischbänke in Litovel (Littau) im Licht der historischen Quellen und archäologischen Forschungen. In: Sborník Národního památkového ústavu, územního odborného pracoviště v Olomouci 2012, 32-47. Olomouc.

- 2013: Pozdně renesanční kachle z Uničova - Spätrenaissance Kachel aus Uničov (Mährisch-Neustadt). In: Sborník národního památkového ústavu územního odborného pracoviště v Olomouci 2013, 15-22. Olomouc.

FALTÝNEK, K.-ŠLÉZAR, P., 2005: Litovel (okr. Olomouc), PV 46, 290-291.

- 2006: Archeologické výzkumy sakrálních staveb v Litovli - Archäologische Forschungen der Sakralbauten in Litovel, AH 31, 303-322.

- 2009: Litovel (okr. Olomouc), PV 50, 399-400.

- 2015: Litovel (okr. Olomouc), PV 56, č. 2, 274-276.

FALTÝNEK, K.-ŠLÉZAR, P.-ZLÁMAL, T., 2015: Předběžné výsledky archeologické výzkumu na Náměstí Přemysla Otakara v Litovli v roce 2014 - Vorläufige Ergebnisse der archäologischen Forschung auf dem Přemysl Otakar Platz in Litovel (Littau) im Jahre 2014. In: Sborník národního památkového ústavu územního odborného pracoviště v Olomouci 2014, 4-14. Olomouc.

GOŠ, V., 2007: Loštice, město středověkých hrnčířů. Opava.

GOŠ, V.-KAREL, J., 2011: Renesanční kachlů ze zámku Janovice u Rýmařova. In: Quod bene notandum Co je třeba zaznamenat. Sborník k 75. narozeninám Jiří Karla (Pohanka, J.-Pohanka, V.-Stanzel, V., edd.), 71-91. Bruntál.

HAZLBAUER, Z.-ŠPAČEK, J., 1986: Poznámky k výrobě reliéfních renesančních kachlů s přihlédnutím k nálezům ve středním Polabí - Bemerkungen zur Herstellung von Reliefkacheln aus der Renaissance im Hinblick auf Funde im Mittleren Elbetal, ČNM A CLV, č. 3-4, 146-165.

HLOŽEK, M.-LOSKOTOVÁ, I., 2015: Příspěvek k mobilitě v kamnářském řemesle - Ein Beitrag zur Mobilität im Hafnerhandwerk, AH 41, 449-460.

HLUBEK, L., 2012: Stř̌edověké kachle z Litovle se znakem pánů z Vlašimi ve sbírkách Vlastivědného muzea v Olomouci, Střední Morava 34, 85-89.

- 2013: Soubor gotických kachlů ze sbírky bývalého Okresního vlastivědného muzea v Litovli - A set of gothic stove tiles in the collection of the former district Regional museum at Litovel, Pravěk NŘ 21, 333-356.

- 2013a: Kachle z Litovle s portréty saských vévodů ve sbírce bývalého Okresního vlastivědného muzea v Litovli, Śląskie Spotkania Archeologiczne LV, 65-73.

- 2013b: Komorové kachle z Litovel s motivem sv. Jiří ve sbírce Vlastivědného muzea v Olomouci, Střední Morava 36, 112-115.

- 2015: Př́íspěvek k výrobě kamnářské keramiky v Lošticích - Contribution to production of stove tiles at Loštice, Pravěk NŘ 23, 219-230.

- 2017: Nové nálezy kachlů s erbem pánů z Vlašimi z Litovle, Střední Morava 43, 104-108.

HLUBEK, L.-FALTÝNEK, K., 2016: Kolekce raně novověkých kachlů z Chořelic (okr. Olomouc) - Collection of Early Modern Tiles from Chořelice (Olomouc District), Zprávy Vlastivědného muzea v Olomouci $312,113-124$.

HLUBEK, L.-FALTÝNEK, K.-ŠLÉZAR, P., 2016: Nález fragmentu kachle z kolekce tzv. rytířských kamen v Litovli - Der Fund eines Kachelfragments aus der Kollektion der sog. Ritteröfen in Litovel, AH 41, 437-447. 
HLUBEK, L.-ŠLÉZAR, P., 2016: Raně novověká kolekce kachlů ze Zahradní ulice v Litovli - Frühneuzeitliche Kollektion von Kacheln aus der Zahradní-Straße in Litovel. In: Sborník památkového ústavu územního odborného pracoviště v Olomouci 2016, 51-65. Olomouc.

HOLUB, P.-JORDÁNKOVÁ, H.-LOSKOTOVÁ, I., 2009: Early Modern period Brno stove tiles with a mosaic (tapestry) pattern, Studies in Post-Medieval Archaeology 3, 273-288.

HOUDEK, V., 1891: Loštice. Rodiště Jana Havelky. Olomouc.

HRBKOVÁ, R., 1970: Litovelská hrnčina. Práce odboru společenských věd Vlastivědného ústavu v Olomouci č. 26. Olomouc.

JAKUBEC, O., 2003: Kulturní prostředí a mecenát olomouckých biskupů potridentské doby - The Culture and Artistic Patronage of the Bishops of Olomouc in the period after Council of Trent. Olomouc.

JORDÁNKOVÁ, H.-LOSKOTOVÁ, I., 2005: Kachlová kamna v prostorách minoritského kláštera v Brně Die Kachelöfen in den Räumen des Minoritenklosters in Brno (Brünn), AH 30, 445-456.

KUBÍN, P., 2004: Zpráva o záchranném archeologickém výzkumu na Brněnské ulici v Mikulově, RegioM: sborník regionálního muzea v Mikulově, 87-102.

KRASNOKUTSKÁ, T., 2005: Středověké a novověké kachle z Opavy - Medieval and Modern Stove-Fitting in Opava. Archaeologiae Regionalis Fontes 8. Olomouc.

LANDSFELD, H., 1947: Co vyráběli novokřtěnští keramikové v Podivíně, VVM 2, 222-238.

- 1950: Lidové hrnčířství a džbánkařství. Besedy o hrnčířství džbánkařském, hrnčířském a kamnářském. Praha.

LANG, A., 1957: Z historie loštického hrnčířství, Severní Morava 1, 27-32.

LOSKOTOVÁ, I., 2008: Ornament na kachlích. In: Krása, která hřeje. Výběrový katalog gotických a renesančních kachlů Moravy a Slezska - Schönheit, die wärmt. Gotische und renessainzeitliche Kacheln aus Mähren und Schlesien (Menoušková, D.-Měřínský, Z., edd.), 139-155. Uherské Hradiště.

- 2009: Ornament v kachlovém reliéfu středověkého a raně novověkého Brna - Ornamentation in Tile Reliefs from Medieval and Early Modern-Age Brno. In: Ornament - oděv - šperk. Archaické projevy materiální kultury. Etnologické studie 5 (Křížová, A. ed.), 9-27. Brno.

LOSKOTOVÁ, I.-DRAGOUN, B.-KOCMAN, F., 2013: Kachlové nálezy na Orlíku. In: Humpolec v zrcadle času V. Archeologie na Humpolecku (Boublík, J.-Brzoň, R.-Dragoun, B.-Hejhal, P.-Chvátal, M.Kašpar, V.-Kocman, F.-Loskotová, I.-Polanský, L.-Rous, P.-Smíšek, K.-Stan, V., edd.), 151-196. Humpolec.

PAJER, J., 1983: Počátky novověké keramiky ve Strážnici - Anfäge der Neuzeitlichen Keramik in Strážnice. Strážnice.

- 1990: A hoard find of the pottery of the area of the Habaner (Anabaptist) court at Strachotín. In: Studies in Post-Mediaeval Archaeology 1 (Smetánka, Z.-Žegklitz, J., edd.), 169-202. Praha.

- 1997: Novokřtěnci v Podivíně. In: Kordiovský, E. a kol., Podivín - vlastivědný sborník jihomoravského města, 184-193. Mikulov.

- 1998: Novokřtěnci v Ostrožské Nové Vsi - Hutterer in Ostrožská Nová Ves, Slovácko XL, 161-182.

- 2006: Studie o novokřtěncích. Strážnice.

- 2015: Nově objevené sídlo novokřtěnců v Čermákovicích (Dvůr Alinkov, k. ú. Horní Kounice, okres Znojmo). In: Sborník Státního okresního archivu Znojmo, 40-59. Znojmo.

PAJER, J. a kol., 2002: Strážnice. Kapitoly z dějin města. Strážnice.

PAVLÍK, Č., 2011: Soubor kachlů z hradu Lukova objevený během záchranných prací (do roku 2009) - Die bei Rettungsarbeiten (bis zum Jahr 2009) entdeckte Kachelkollektion von Burg Lukov, AH 36, 557-571.

PAVLÍK, Č.-VITANOVSKÝ, M., 2004: Encyklopedie kachlů v Čechách, na Moravě a ve Slezsku. Ikonografický atlas reliéfů na kachlích gotiky a renesance. Praha.

PINKAVA, V., 1903: Litovelský okres. Brno.

RUTTKAY, M., 2008: Kachlice z hradu v Topol'čiankach - Kacheln aus der Burg in Topol'čianky, ŠZ AÚ SAV 43, 121-231.

ŘÍHOVÁ, V., 2010: Biskup, hrnčíř a střepy z nádvoří olomouckého děkanství - Bishop, potter and fragments from the courtyard of the Olomouc deanery. In: Arcidiecézní muzeum na Olomouckém hradě (Jakubec, O., ed.), 210-218. Olomouc.

ŠEBELA, L.-VANĚK, J., 1985: Hromadný nález ze studny v areálu bývalého bratrského sboru v Ivančicích - Massenfunde aus dem Brunnen im Areal der ehemaligen Brüdergemeine der Böhmishen Brüder in Ivančice. Ivančice.

ŠLÉZAR, P., 2006: Litovel (okr. Olomouc), PV 47, 255.

- 2008: Kostely a sakrální stavby v Litovli - Churches and Sacred Buildings in Litovel. Archeologické památky střední Moravy 17. Olomouc. 
- 2016: Archeologické poznanie malého královského mesta na Moravě - Archeological knowledge of a small royal town in Morava, rkp. nepubl. disertační práce na KA FF UKB, Bratislava, vedoucí práce doc. PhDr. Michal Slivka, CSc.

TYMONOVÁ, M., 2014: Výroba kamnářské keramiky v českých zemích a dílna v Opavě - Belege für die Herstellung von Ofenkeramik in den Ländern Böhmens und eine Werkstatt in Opava, AH 39, $155-175$.

- 2015: Medailonové kachle z Javorníka - Die Medaillonkacheln aus Javorník, AH 40, 941-955.

WINTEROVÁ, A., 2016: Pozdně středověké a raně novověké reliéfní kachle z Boskovic - Late Medieval and Early Modern relief stove tiles from Boskovice, rkp. nepubl. bakalářské práce na FF MU, Brno, vedoucí práce PhDr. Irena Loskotová, Ph.D.

\section{Zusammenfassung}

\section{Kacheln mit fünf kreisförmigen Vertiefungen aus dem Areal der Stadt Litovel}

Zur Zeit werden die aus dem Areal der Stadt Litovel stammenden Kollektionen an Ofenkeramik nach und nach bearbeitet. Besonders in den in die frühe Neuzeit gelegten Kollektionen an Ofenkeramik fand man relativ häufig Exemplare vor, auf deren Blatt sich fünf kreisförmige Vertiefungen befanden, die in mehreren verschiedenen archäologischen Grabungen fast als einzige als solche erfasst wurden (Abb. 1). Ein häufigeres Vorkommen verzeichnen wir im historischen Zentrum der Stadt (Markuskirche und in den Straßen Komenského, Revoluční, Masarykova und Husova), jedoch kennen wir sie auch aus dem Areal der Altstadt bei Litovel (Grabung in der Straße Zahradní).

Insgesamt ist es gelungen, 18 Fragmente von Grundkacheln zusammenzutragen, auf deren Blatt wir fünf kreisförmige Vertiefungen vorfinden oder vermuten (Abb. 2-4). Eine Eckkachelvariante mit zwei kreisförmigen Vertiefungen wurde insgesamt an acht Fragmenten und an einem fast ganz zusammengeklebten Exemplar identifiziert (Abb. 5). Lediglich das größte Kachelfragment hat eine unglasierte Oberfläche, alle übrigen Stücke wurden entweder mit einer hellen oder sattgrünen Glasur versehen, deren Grundstoff weißer Ton ist. Die Kacheln aus den Straßen Revoluční und Zahradní haben an den Kanten noch eine braune Glasur. Gemäß den charakteristischen technisch-technologischen Erkenntnissen (z.B. Zargentiefe, grüne Glasur des Blattes, Textilfaserabdrücke auf der Kachelrückseite) und aufgrund ähnlicher Funde aus Mähren und Schlesien können wir sie in die frühe Neuzeit datieren, genauer gesagt in das Zeitintervall zwischen der zweiten Hälfte des 16. Jahrhunderts und dem ersten Drittel des darauffolgenden Jahrhunderts.

Die Kacheln mit fünf kreisförmigen Vertiefungen weisen eine beträchtliche Verwandtschaft mit der Gruppe von Kacheln auf, die über eine zentrale medaillonförmige Vertiefung verfügen und als charakteristische Erzeugnisse der Töpfer aus den Reihen der Wiedertäufer angesehen werden. Bei den bisher bekannten Funden von Kacheln mit fünf kreisförmigen Vertiefungen aus dem Umfeld von Wiedertäuferwerkstätten wird die Vertiefung in der Mitte jedoch nicht von einer plastischen Leiste gerahmt, so wie dies bei den Funden aus Litovel der Fall ist. Anders ist auch die Herstellungsweise der Eckexemplare. Bei den Funden aus der Stadt Litovel werden die Ecken durch zwei schräg zugeschnittene und zueinander gesetzte Kacheln gebildet, während man bei den Erzeugnissen der Wiedertäufer eine herstellungsmäßig anspruchsvollere Variante von Eckkacheln mit abgeschrägten Ecken vorfindet.

Es ist sehr wahrscheinliche, dass die hier vorgestellten Funde als Nachahmungen bezeichnet werden können, die auf Vorlagen der Wiedertäufer basieren. Aufgrund der oben aufgeführten Tatsachen nehmen wir an,, dass die Kacheln mit fünf kreisförmigen Vertiefungen irgendwo im mittelmährischen Raum hergestellt worden sind. Als einen wahrscheinlichen Ort ihrer Herstellung erlauben wir uns das Städtchen Loštice zu nennen, obwohl es auch möglich ist, dass sie in mehreren Werkstätten gleichzeitig hergestellt worden sein können.

Mgr. Lukáš Hlubek, Vlastivědné muzeum v Olomouci, náměstí Republiky 5, 77173 Olomouc, Česká republika,hlubek@vmo.cz 
